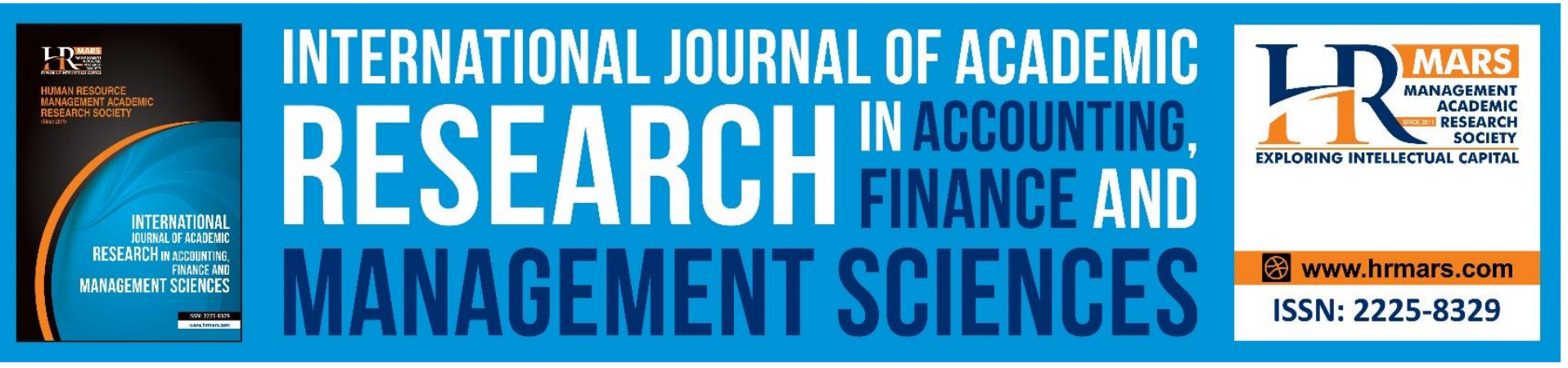

\title{
Evaluation of the Employees' Provident Fund in Jordanian Public Universities
}

Fawzi A. Al Sawalqa, Ghazy A. Al-Badainah

To Link this Article: http://dx.doi.org/10.6007/IJARAFMS/v10-i3/7900 DOI:10.6007/IJARAFMS/v10-i3/7900

Received: 03 July 2020, Revised: 24 July 2020, Accepted: 28 August 2020

Published Online: 30 September 2020

In-Text Citation: (Al Sawalqa, \& Al-Badainah, 2020)

To Cite this Article: Al Sawalqa, F. A., \& Al-Badainah, G. A. (2020). Evaluation of the Employees' Provident Fund in Jordanian Public Universities. International Journal of Academic Research in Accounting, Finance and Management Sciences. 10(3), 256-277.

Copyright: (c) 2020 The Author(s)

Published by Human Resource Management Academic Research Society (www.hrmars.com)

This article is published under the Creative Commons Attribution (CC BY 4.0) license. Anyone may reproduce, distribute, translate and create derivative works of this article (for both commercial and non-commercial purposes), subject to full attribution to the original publication and authors. The full terms of this license may be seen

at: http://creativecommons.org/licences/by/4.0/legalcode

\section{Vol. 10, No. 3, 2020, Pg. 256 - 277}




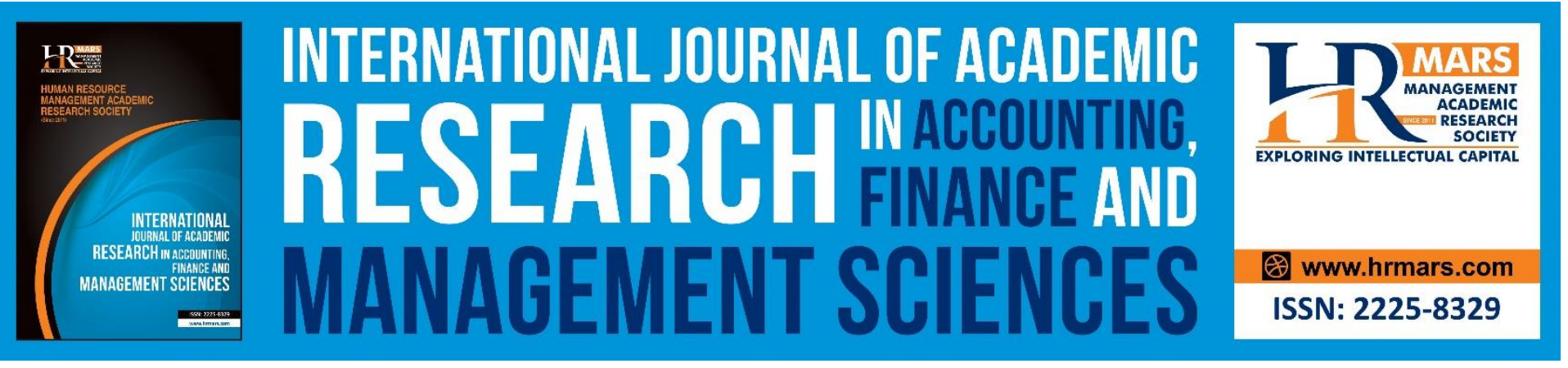

\title{
Evaluation of the Employees' Provident Fund in Jordanian Public Universities
}

\author{
Fawzi A. Al Sawalqa, Ghazy A. Al-Badainah \\ Faculty of Business, Tafila Technical University, P. O. Box 179, Tafila 66110, Jordan \\ Email: fsawalqah@ttu.edu.jo, Ghazy70312005@yahoo.com
}

\section{Abstract}

The current initial study comes to explore the current status and the future trend of the Employees' Provident Fund (EPF) among Jordanian public universities. Based on the responses of 167 employees from two public universities, the results show a weak investment policy in EPF and a general unsatisfactory attitude towards the current status of EPF investments. Uncertainty in the future of EPF and the scarcity of financial resources are the main barriers of investing in EPF. Employees stress numerous future corrective actions to enhance the role of EPF in serving the members. Results also show that the monthly salary is the key factor that affects the perception of employees towards the current status of EPF investments, barriers of investments in EPF, and the future corrective actions of EPF. As a rare study in EPF in universities, it offers valuable recommendations to policy-makers to develop the different perspectives of EPF.

Keywords: Employees' Provident Fund, Jordanian Public Universities, Investment, Future Corrective Actions

\section{Introduction}

The main objective of EPF is to offer some social protection to employees by transferring regular monthly contribution to their EPF accounts (e.g. Dixon, 1982; Dixon, 1993; Zin 2012) taken from employees and employers. The concept of provident fund was defined early by Dixon (1982, p. 328) as a compulsory saving program "covered employees and their employers pay regular contributions to a central, publicly-supervised fund where they are credited to a separate account maintained for each employee". However, the provident fund is one of the pension plans in some countries (Nazir, Hamidullah \& Hussain, 2010), and paid to the member upon retirement or to the beneficiary on the death of the member (Unachukwu, Oladeji \& Egunjobi, 2020).

The EPF instructions are different from one country to another and even from one organization to another in case of Jordan. Therefore, in case of Jordan the EPF is additional social security system, worked on the level of the organizations and can be withdrawn before the stage of retirements. Therefore, not all the organizations in Jordanian have EPF. For example, the public universities in Jordan have EPF, while the private universities have not. Thus, it is not a compulsory system at the level of country in Jordan. This is because Jordan has a social security system applied 
on all the organizations and is compulsory at the level of the whole country. Therefore, in Jordan the EPF is a welfare system covered by written instructions that may vary from one organization to another and is subject to mixed features taken from those of both savings and pension schemes.

It has been argued that the EPF in developing countries should be expanded to include all organizations (Damle, 2016). The suitability of social protection programs is evaluated based on their role in improving the living conditions of members (e.g. Chalamwong \& Meepien, 2012). For example, Singapore has a retirement investment system for central provident fund permits members to select the investment path proper to maximize their retirement returns (Koh \& Mitchell, 2010; Koh, Mitchell \& Fong, 2010). In his study, Zin (2012) tried to assess the extent to which Malaysian social security programs are fair and appropriate. Similarly, Asher and Bali (2013) investigated the sustainability of Singapore's pension system with some emphasis on central provident fund. Furthermore, Siu (2002) concludes that Singapore's central provident fund system is an important protection instrument for retirees in Singapore.

Thus, it is necessary from time to time to evaluate the rules and policies that govern the pension programs and to assess their current status, barriers and future trend (Holzmann, 2013). In the same context, it has been noted that some universities do not direct the EPF to sound investment projects, which creates some dissatisfaction among members. In addition, there are some limitations in the accounting systems used to account for EPF (e.g. Bepristis \& Yin, 2006; Klumpes, 2011). Thus, the current study comes to evaluate the current status of the EPF and to outline the perception of their members towards the future mechanisms that must be employed to develop EPF in Jordanian public universities. Notably that the current study is one of the few studies to employ the statistical methods to describe the status of EPF, as most of previous studies (e.g. Lindeman, 2002; Jones, 2005; Alam, 2010; Hamid \& Tyng, 2013) employed the theoretical approach to investigate the status of provident funds in different countries. In addition, most of previous studies in this topic tried to investigate the status of the national provident fund and how it will offer some protection to their members during their retirement stage. They identified the main challenges and-in most of themoffered some theoretical solutions. This means that previous studies have ignored the provident fund in universities, and accordingly very few information are available about the perception of members towards the different issues of provident funds in developing countries (Chu \& McKenzie, 2008; Budsaratragoon et al., 2012). Accordingly, the current study- to the best of my knowledge- is the first to focus on EPF in universities. Therefore and in light of the lack of prior studies in this vital topic, this study is considered an important addition to the knowledge in the field as it comes to achieve the following objectives:

- Determine the pattern in which respondents wish to withdraw their accumulated balances in the EPF.

- Identify the main investment aspects being used among Jordanian universities for EPF.

- Identify the perception of employees towards the following:

- a. The current status of EPF investments.

- b. The accounting system being used to account for the EPF.

- c. The barriers that face the investment of the EPF.

- d. The future corrective actions of EPF. 
INTERNATIONAL JOURNAL OF ACADEMIC RESEARCH IN ACCOUNTING, FINANCE AND

MANAGEMENT SCIENCES

Vol. 10 , No. 3, 2020, E-ISSN: $2225-8329$ @ 2020 HRMARS

\section{Provident Fund System in Jordanian Universities}

In Jordan the decision to establish EPF is left to organizations as it is considered as additional incentives to employees. Such EPF is different in Jordan from the social security system. That is, Jordan has a mandatory social security system provides members with monthly salary in their retirement stage, while the EPF gives the member the right to withdraw part of it during the work stage or to withdraw the full balance upon retirement. Contrary to the social security system, which is compulsory and managed by the government, not all organizations have their own EPF in Jordan. Therefore, it is another social security protection policy to protect employees (e.g. Chan, 2003).

Jordan has 10 public universities and 19 private universities. In Jordanian public universities, the employees are compulsory required to join the EPF by taking a specific percentage from their monthly salary and then added to their accounts in EPF along with contribution of the university, and both are calculated based on the basic monthly salary of employee (e.g. Chan, 2003; Ramesh, 2014). Each public university has its own EPF that governed through official instructions. In Jordanian universities, EPFs were issued based on article No. 26 of the abolished Temporary Public Jordanian Universities Law No. 42 of the year 2001. In recently established universities, the foundation of EPFs was based on article No. 33 of Jordanian Universities Law No. 20 of 2009 and its amendments. The Jordanian University law No. 18 of 2018 gives the universities the right to establish EPFs in Article (32). The general regulations of EPF, in most of Jordanian universities, are similar, while the instructions are almost different depending on the investment tendency of each university. For example, some universities depend on the Islamic system to account for the credit facilities given to their employees, while some depend on the commercial one (e.g. Nazir, Hamidullah \& Hussain, 2010).

In general, it can be argued that the investment in EPF is influenced by three main factors including:

1. The age of the university: for example, old universities have more employees and accordingly the accumulated balances of EPF are larger than those of young ones.

2. The geographic location of the university: for example, universities in Jordan distributed over three main regions including northern region, central region and southern region. The central region includes the capital city "Amman" and other big cities in Jordan. In addition, the central region is the most developed region in Jordan and has an active business market. Accordingly, the investment opportunities are much better for those universities located in central region than those of northern or southern regions.

3. The efficiency of EPF management committee: away from the previous two factors, the existence of efficient management committee can help members in selecting appropriate investment opportunities and to balance between risk and return (Davis, 2005).

\section{Previous Literature and Hypotheses Development}

The current study focuses on those studies that empirically investigated the status of EPF in universities. But unfortunately and at the best of the researchers' knowledge, no studies have focused on EPF in universities, while most of them have focused on other pension schemes that contribute to retirement of employees at national levels. These include, for example, national provident funds in six African countries in Gerdes (1971), Zambian national provident fund in Godfrey (1974), Hong Kong mandatory central provident fund in Vasoo and Lee (2001), Siu (2002), Chan (2003) and Chu and McKenzie (2008), Fiji national provident fund in White (2005), Singaporean 
central provident fund in Jones (2005), Koh, Mitchell and Fong (2008) and Koh and Mitchell (2010); Chinese housing provident fund in Burell (2006) and Chen and Deng (2014), Pakistan general provident fund in Nazir, Hamidullah and Hussain (2010), Indian mutual fund in Saha and Dey (2011), employees' provident fund of Sri Lanka in Kumara and Pfau (2012), Malaysian employee provident fund in Thillainathan (2000), Jidwin, Tuyon and Ali (2011) and Hamid and Tyng (2013), Indian employees' provident fund in Shanmugasundaram (2008), Asian (Singapore, Malaysia, India and Sri Lanka) provident funds in Lindeman (2002) and Alam (2010).

However, most of the above mentioned studies came from Southeast Asian countries, which try to reproduce the western model in managing the provident funds especially that of Australia, the geographical neighbor for most of them (e.g. Devereux, 2013). In addition, it looks that Southeast Asian countries have put more emphasis on different social protection plans as a result of 1990s financial crisis (Cook \& Pincus, 2014), which also encouraged researchers to focus on such topic.

The relevant studies for the current study are those focused on investment polices of EPV, barriers and challenges, accounting system and future corrective actions of EPV.

Early, Gerdes (1971) described the status of national provident fund programs in six African countries throughout 1960s. The author briefly described the structure and administrative policy of the program. The author also criticized the low monthly contributions by the members. Dixon (1993) assessed the status of national provident funds in 23 developing countries. The author highlighted three important challenges that may limit the ability of national provident funds to face the future requirements. These include, low periodic contribution, uncertainty about the efficiency of lump-sum payment, and finally the failure of provident funds managers to reduce the influence of inflation (see also Dixon, 1982; Cook \& Pincus, 2014).

Lindeman (2002) investigated the current and future trend of provident funds in four Asian countries including Sri Lanka, India, Singapore and Malaysia. The author noted that both Singapore and Malaysia are started to manage provident funds in accordance to the corporate governance principle in transparency and accountability, with Singapore as the dominant in this area amongst the four countries (see also Jones, 2005). The author expects similar procedures in other two countries, but not in the near future as many factors may limit such improvements in managing provident funds (see also, Kumara \& Pfau, 2012). Jones (2005) discussed the challenges to the investments of central provident fund that may affect the returns of retirement stage in Singapore. Examples of such challenges were the inability of members to select the relevant investment projects and the competitive ability of economy. To deal with such challenges, the author asked decision makers to put more constraints on the using of provident funds outside the requirements of retirement stage. In the same context, Koh, Mitchell and Fong (2008) investigated the factors that may affect the costs that accompanying with the investment decisions of central provident fund in Singapore and the potential solutions to decline such costs. Authors suggested some solutions to decrease such costs and to maximize the potential returns. Alam (2010) tried to develop a legal frame for provident funds in developing countries such as Bangladesh simulates that of developed countries. The author argued that one severe problem in pension system in Bangladesh and other developing countries in comparison with that of developed countries is the lack of appropriate corporate governance practices. Jidwin, Tuyon and Ali (2011) surveyed the employee provident fund members in Malaysia to evaluate the appropriateness of their investments in unit trusts. Authors' findings indicated that there is no stable return over time, which means that the risky is possible for 
such investments. Authors justified such result in that the investment decision is in general influenced by many factors such as knowledge of member, availability of relevant information and financial advice (e.g. Saha \& Dey, 2011; Kathuria \& Singhania, 2012). Similarly, Koh and Mitchell (2010) investigated the eligibility of investment opportunities of Singapore's central provident fund. In particular, several options are offered for all members of Singapore's central provident fund to invest a portion of their balances. Authors tried to evaluate the return of such investment in comparison with other opportunities that excluded from the investment list. Results indicated that the invested fund gained greater return than the excluded one in many dimensions. One important implication of Koh and Mitchell (2010) study is that offering such investment options to participants is an important step in decreasing the associated risk of investment decisions, especially to prudent investors who used to face several difficulties in selecting an appropriate investment path. This implication is consistent with the findings of Wu and Wang (2003) who found that central provident fund plays a serious role in Singapore's financial market. In addition, Koh, Mitchell and Fong (2010) performed a study to evaluate the behavior of members in improving their return in Singapore's central provident fund by getting professional consultants. Result of study indicated that it is difficult to have a stable high return over time. Hassan and Othman (2018) performed a study to evaluate the ability of provident fund to fulfill its future obligations towards the different beneficiaries in Malaysia. The results showed that the future of the employees' provident fund is positive in light of the existence of an effective management and it is likely that it will face the requirements of retirees and will also contribute in developing the country. Hassan, Othman and Din (2018) surveyed 300 beneficiaries to assess their perceptions towards EPF in Malaysia in term of the factors that may impact the potential retirement returns. Results revealed that loans of housing and cars and the medical expenditures influence the retirement proceeds sufficiency negatively. However, more improvements are needed for the Malaysian employees' provident fund to fulfill its future obligations effectively. Zhu (2019) performed a study to investigate the effect of provident fund on the investment in stock market in china. Results indicated that families that have contributions in provident fund have a greater desire to invest in the securities market. Estrada, Koutronas and Park (2019) performed a study on the Malaysian provident fund in terms of the procedures necessary to reform it and the expected effect on decreasing the poverty rate and increasing the benefits. For example, results indicated that increasing the compulsory monthly contributions and inclusion all the types of labors in provident fund program will enhance the income and life of members.

The above mentioned studies tried to identify the main barriers and challenges that face national provident funds in achieving their objectives. The limitation of most of these studies is that they did not consider the perception of members towards the possible solutions and suggestions for such barriers and challenges. In addition, prior studies in the field could not develop the relevant legal frameworks to manage such fund. Moreover, previous studies have not evaluated the accounting systems and approaches used to account for EPF. However, it has been noted that the prior studies that have focused on EPF in universities are not found, which gives the current study exceptional importance as it will contribute to the knowledge in this field and will offer an important reference to future studies that may investigate EPF in universities. 


\section{Hypotheses Development}

Since the current study focuses on the perception of universities' employees towards important issues in respect to the EPF, it can be argued that their perceptions may be affected by some of their demographic characteristics. In particular, three characteristics may affect the perception of respondents towards the main issues of the EPF (i.e. current status of investments, accounting system, barriers of investments and future corrective actions). These include:

1. Nature of work (i.e. academic and administrative)

2. Monthly salary

3. Tenure of university work

Accordingly, the following hypotheses were developed and will be tested based on the collected data to offer the necessary conceptual and theoretical framework for EPF in universities:

First group: Nature of work

$H 1$. There is a significant difference in the perception of employees towards the current status of EPF investments due to their nature of work.

$H 2$. There is a significant difference in the perception of employees towards the accounting system used to account for EPF due to their nature of work.

H3. There is a significant difference in the perception of employees towards the barriers of investment in EPF due to their nature of work.

H4. There is a significant difference in the perception of employees towards the future corrective actions of EPF due to their nature of work.

Second group: Monthly salary:

$H 5$. There is a significant difference in the perception of employees towards the current status of EPF investments due to their monthly salary.

H6. There is a significant difference in the perception of employees towards the accounting system used to account for EPF due to their monthly salary.

$H 7$. There is a significant difference in the perception of employees towards the barriers of investment in EPF due to their monthly salary.

H8. There is a significant difference in the perception of employees towards the future corrective actions of EPF due to their monthly salary.

Third group: Tenure of university work

H9. There is a significant difference in the perception of employees towards the current status of EPF investments due to their tenure of university work.

H1O. There is a significant difference in the perception of employees towards the accounting systems used to account for EPF due to tenure of university work.

H11. There is a significant difference in the perception of employees towards the barriers of investment in EPF due to tenure of university work.

H12. There is a significant difference in the perception of employees towards the future corrective actions of EPF due to tenure of university work. 
INTERNATIONAL JOURNAL OF ACADEMIC RESEARCH IN ACCOUNTING, FINANCE AND

MANAGEMENT SCIENCES

Vol. 10 , No. 3, 2020, E-ISSN: 2225-8329 @ 2020 HRMARS

\section{Methodology}

This section covers the methods used in collecting the data for the current study along with the techniques used to analyses and test the study hypotheses.

\section{Sample Selection}

Jordanian public universities are distributed along three main regions including northern region, central region and southern region. 4 universities are located in the northern region, 3 in central region and 3 in southern region. The population of the current study includes all the academic and administrative employees of two public Jordanian universities that lay at the southern region. The justification for selecting these two universities is based on the notion that far distance between these two universities and the capital, Amman- which is the Jordanian economic center- means limited investment opportunities in southern region. This, however, shows the problem of study more deeply and provides the decision-makers in these two universities with the necessary solutions to manage EPF. In addition, the other public universities that lay in central and northern regions were excluded from the current study due to the variance between such universities and the universities of the Southern region in many issues such as age, size and the available investment opportunities.

\section{Data}

The current study is considered the first in context of Jordan. Thus, a considerable efforts were exerted to develop an appropriate comprehensive questionnaire covers most of the EPF issues. In particular, the following procedures were employed to develop an appropriate questionnaire:

1. Most of the EPF instructions of different Jordanian universities were investigated.

2. A broad set of related prior research in different pension plans and EPF systems were investigated.

The above mentioned procedures were employed to ensure the reliability and validity of the contents of the questionnaire. The final version of the questionnaire includes six sections. The development of these sections is based mainly on the experience of the researchers and the theoretical framework of prior research in the field (e.g. Gerdes, 1971; Dixon, 1993; Siu, 2002; Hassan \& Othman, 2018; Estrada, Koutronas \& Park, 2019). The first section includes 7 questions. 6 of them collect the relevant demographic information of respondents with the last question asks respondents to choose the relevant method they prefer to withdraw their accumulated balance in the EPF. Section two focuses on the main perspectives of investments for the accumulated balances of EPF in Jordanian university. This section was formulated based on three responses ( $1=$ yes, $2=$ No, and $3=1$ do not know). Section three focuses on the perception of respondents towards the current status of EPF investments in Jordanian public universities. Section four evaluates the accounting system used in EPF. Section five lists the possible barriers that may face EPF investments. Finally, section six focuses on the perception of respondents towards the future of EPF in Jordanian universities through 16 possible corrective actions. All the questions of study are close-ended. The five-point Likert scale was used to formulate the last five sections of the questionnaire. The questionnaire includes at its last page a general open-end question gives the respondents the chance to express their opinions at any part of the questionnaire. The questionnaire was distributed online to the study sample. This process resulted in 167 usable questionnaires. Table 1 shows the demographic characteristics of the respondents. In particular, Table 1 shows that most of the respondents were males (64.1\%) and most 
of their ages (74.2\%) ranged from 30 years to less than 50 years. In addition, most of the respondents (65.3\%) are administrative in their universities. This is normal as the administrative staff in Jordanian universities is larger than the academic one. The results show that the respondents are well educated as $74.3 \%$ of the respondents have a bachelor degree or above. This supports the reliability of the questionnaire and increases the confidence in the results of the study. In respect to the monthly salary, results show that more than half $(55.7 \%)$ of the respondents get a salary ranged from $500 \mathrm{JOD}$ to less than 1000 JOD. Finally, about $82.1 \%$ of the respondents have an experience ranged from 5 years to less than 30 years in their universities.

Table 1. Background information of participants

\begin{tabular}{|c|c|c|c|c|c|}
\hline & Frequency & $\%$ & & Frequency & $\%$ \\
\hline Gender & & & Monthly salary & & \\
\hline Male & 107 & 64.1 & Less than $500 \mathrm{JOD}$ & 37 & 22.2 \\
\hline Female & 60 & 35.9 & 500-less than 1000 & 93 & 55.7 \\
\hline total & 167 & 100.0 & 1000 -less than 1500 & 24 & 14.4 \\
\hline Age & & & 1500-less than 2000 & 7 & 4.2 \\
\hline Less than 30 & 16 & 9.6 & 2000-less than 2500 & 2 & 1.2 \\
\hline $\begin{array}{r}30-\text {-ess than } \\
40\end{array}$ & 61 & 36.5 & 2500-less than 3000 & 2 & 1.2 \\
\hline $\begin{array}{l}\text { 40- less than } \\
50\end{array}$ & 63 & 37.7 & 3000-less than 3500 & 2 & 1.2 \\
\hline 50 and above & 27 & 16.2 & 3500 and above & 0 & 0 \\
\hline Total & 167 & 100.0 & Total & 167 & 100.0 \\
\hline $\begin{array}{l}\text { Nature of } \\
\text { work }\end{array}$ & & & $\begin{array}{l}\text { University } \\
\text { experience }\end{array}$ & & \\
\hline Academic & 58 & 34.7 & Less than 5 years & 30 & 18.0 \\
\hline Administrative & 109 & 65.3 & 5-less than 10 & 21 & 12.6 \\
\hline Total & 167 & 100.0 & $\begin{array}{l}\text { 10-less than } 15 \\
\text { years }\end{array}$ & 31 & 18.6 \\
\hline Qualification & & & 15 -less than 20 & 28 & 16.8 \\
\hline PhD degree & 35 & 21.0 & 20-less than 30 & 57 & 34.1 \\
\hline $\begin{array}{l}\text { Master } \\
\text { degree }\end{array}$ & 31 & 18.6 & 30 years and above & 0 & 0 \\
\hline $\begin{array}{r}\text { Bachelor } \\
\text { degree }\end{array}$ & 58 & 34.7 & Total & 167 & 100.0 \\
\hline Diploma & 25 & 15.0 & & & \\
\hline other & 18 & 10.8 & & & \\
\hline Total & 167 & 100.0 & & & \\
\hline
\end{tabular}

As the current study depends on new variables formulated by the authors depending on investigation of abroad set of prior studies, the internal consistency (Nunnally, 1978) of the main sections of the study was measured based on the questions of each section. Table 2 shows the 
Cronbach alpha test results. All the Cronbach alpha values are ranged from 0.863 to 0.955 , which indicates satisfactory internal reliability of the scales used in the current study. These results are considered new addition to the current literature in the field and future studies may depend on the current variables to perform several empirical studies.

Table 2: Internal consistency of the study main variable

\begin{tabular}{lccc}
\hline Section title & No. of items & Mean & Cronbach's Alpha \\
\hline Current status of EPF investments & 5 & 2.774 & 0.868 \\
Accounting system used in EPF & 6 & 3.034 & 0.890 \\
Barriers of the investments in EPF & 11 & 3.253 & 0.863 \\
Future corrective actions of EPF & 16 & 3.710 & 0.955 \\
\hline
\end{tabular}

\section{Results and Discussion}

To achieve the objective of the study and to test the hypotheses, the descriptive statistics, Independent-Sample T-test and One Way ANOVA test were used. The results are outlined in the next sub sections.

\section{Descriptive Statistics}

Withdrawal Patterns of Accumulated Balances in EPF

According to the first objective of the study, three patterns were outlined in the questionnaire about the way that respondents wish to withdraw their accumulated balances in the EPF. Table 3 shows the responses. The results show that $44.3 \%$ of the respondents wish to withdraw their accumulated balances according to their emergency needs, while only $28.7 \%$ of the respondents wish to get their balance at a multiple payments during their work time. Finally, $26.9 \%$ wish to get a lump sum payment upon retirement. This result is consistent with the argument of Dixon (1993), who sees that the lump-sum payments are one of the challenges that may affect the ability of EPF to meet the future obligations. These results indicate that the employees in general wish to withdraw their accumulated balances according to their needs.

Table 3. Withdrawal patterns of accumulated balances in EPF

\begin{tabular}{lcc}
\hline Pattern of withdrawing & Frequency & \% \\
\hline Lump-sum payment upon the retirement & 45 & 26.9 \\
Multiple payments during my service & 48 & 28.7 \\
According to my emergency needs & 74 & 44.3 \\
\hline Total & 167 & 100.0 \\
\hline
\end{tabular}

\section{The Investment Aspects of EPF}

The second objective of the current study seeks to identify the main aspects of investments for the accumulated balances of EPF in Jordanian university. The respondents were asked to answer this question according to three responses $(1=y e s, 2=$ no, and $3=1$ do not know). Table 4 shows the mean values of the investment perspectives. Most important, results show the ascending ranks of the ten items. The mean for the first investment perspective is 1.7305 and ranked first among the other items. This result means that universities of Jordan focus in the first instance on investing the 
accumulated funds in loans to their employees for relevant returns. The second investment opportunity is to finance the purchases of employees at relevant returns. The last investment opportunity is to invest in securities and adding their return to balances of participants, which ranked tenth, with a higher mean of 1.9341. In general, it looks that the current investment policy of the EPF in Jordanian universities is very weak as the mean values are skewed toward 2 "No" and 3 "Do not know" and are focused on less-risky perspectives that have very low return. In addition, it looks that some of the respondents have no idea about the investment policy of EPF, which means that they are not involving in the decision-making process. Thus, the uncertainty is the dominant in answering this question.

To improve the return of EPF and to decrease the associated risks, Koh and Mitchell (2010) suggested that several investment opportunities should be offered to the members to select the relevant from them. This procedure is also important in giving the members the opportunity to participate in the investment decision making process in EPF.

Table 4. The investment aspects of EPF.

\begin{tabular}{lcc}
\hline Investments aspect & Mean & Rank \\
\hline B1. Providing personal loans to members against a relevant return & 1.7305 & 1 \\
B9. Finance the consumer purchases for members against a relevant return & 1.7844 & 2 \\
B4. Providing loans to members to purchase lands against a relevant return & 1.8024 & 3 \\
B6. Buying lands to members against relevant price and return. & 1.8024 & 3 \\
B7. Buying apartments to members against relevant price and return. & 1.8084 & 5 \\
B3. Providing loans to members to purchase cars against a relevant return & 1.8263 & 6 \\
B2. Providing housing loans to members against a relevant return & 1.8383 & 7 \\
B10. Managing commercial and service projects and adding the return to the & 1.8503 & 8 \\
balances of members. & & 9 \\
B5. Deposit the money of EPF in a fixed deposit account against a return added & 1.8862 & \\
to the balances of members. & & 10 \\
B8. Managing investment portfolios in stock and bonds and adding the return & 1.9341 & \\
to the balances of members. & Total & 1.8263 \\
\hline
\end{tabular}

\section{Evaluation of the Current Status of EPF Investments}

One of the objectives of the current study is to investigate the perception of Jordanian universities employees towards the current status of EPF investments. In particular, respondents were asked at a 5-point likert scale ( $1=$ strongly disagree, $5=$ strongly agree), to evaluate the current status of the EPF. It looks that all the mean values are small and the total mean value for all the five questions is 2.7737, which indicates that the current investment strategy do not meet their desires. To support the results, the first question asked respondents explicitly about the extent of their satisfaction with the way the universities used to invest EPF. The mean value for the responses ranked last (2.5210), which means that the respondents are not satisfied with the investment policies used for EPF in Jordanian universities in terms of credit facilities, management, strategic plan and return. This result is inconsistent with that of Siu (2002) who found a general satisfaction about the 
INTERNATIONAL JOURNAL OF ACADEMIC RESEARCH IN ACCOUNTING, FINANCE AND MANAGEMENT SCIENCES

Vol. 10 , No. 3, 2020, E-ISSN: 2225-8329 @ 2020 HRMARS

Singapore's central provident fund and that of Hassan and Othman (2018) in respect to Malaysian EPF.

These results can be justified based on the findings of Jidwin, Tuyon and Ali (2011) who noted that there is no fixed return from the EPF in Malaysia and attributed that to several factors such as the knowledge of employees, extent of availability of relevant information and the usage of relevant financial tools.

Table 5. Evaluation of the current status of EPF investments

\begin{tabular}{lcc}
\hline Item & Mean & Rank \\
\hline C3. There are a variety of loans that I can get from EPF at reasonable terms & 2.9880 & 1 \\
C5. EPF is managed by a qualified team of the university employees & 2.8922 & 2 \\
C4. The university has strategic investment plans to invest in EPF and to ensure its & 2.7904 & 3 \\
sustainability \\
$\begin{array}{l}\text { C2. The investments in EPF achieve relevant returns that are added to my balance } \\
\text { periodically. }\end{array}$ \\
$\begin{array}{l}\text { C1. I am satisfied with the way the university invests the money of EPF. } \\
\text { Total }\end{array}$ & 2.5210 & 5 \\
\hline
\end{tabular}

\section{Evaluation of the Accounting System used in EPF}

The respondents were also asked on a five-point likert scale ( $1=$ strongly disagree, 5= strongly agree) to express their opinion towards the accounting system used for EPF. Table 6 shows the mean values for the six items. In particular, it looks that the respondents' answers are concentrated in the neutral point as the total mean value is 3.0339. This result indicates that most of the respondents were not familiar with the accounting system that used to account for EPF. This result also supports the above mentioned result, which indicated that Jordanian employees are not satisfied with the EPF current investment policy.

Table 6. Evaluation of the accounting system used for EPF

\begin{tabular}{lcc}
\hline Item & Mean & Rank \\
\hline D4. The accounting system used in EPF enables me to get a historical record to & 3.1976 & 1 \\
all my transactions in EPF. & 3.1078 & 2 \\
D1. I can easily calculate my balance at the EPF at any time & 3.1078 & 2 \\
D6. A Periodic full auditing is performed to EPF. & 2.9701 & 4 \\
D2. I can easily know the returns added to my balance in EPF at any time & 2.9341 & 5 \\
$\begin{array}{l}\text { D5. Full financial statements that describe the financial position and results of } \\
\text { EPF are prepared }\end{array}$ & 2.8862 & 6 \\
$\begin{array}{l}\text { D3. The accounting system used in EPF enables me to easily compute the cost } \\
\text { of my credit facilities. }\end{array}$ & 3.0339 \\
\hline Total
\end{tabular}


INTERNATIONAL JOURNAL OF ACADEMIC RESEARCH IN ACCOUNTING, FINANCE AND

MANAGEMENT SCIENCES

Vol. 10 , No. 3, 2020, E-ISSN: 2225-8329 @ 2020 HRMARS

\section{Barriers of the Investments in EPF}

The respondents were asked on a five-point likert scale ( $1=$ strongly disagree, $5=$ strongly agree) to express their opinion about the barriers and challenges that face the EPF investments. As shown in Table 7, the total mean value of all barriers is 3.2531. This result indicates that the respondents almost approve the most of the listed barriers. However, the results also include the ranking of each challenge according to its mean. It looks that the problem of uncertainty is the dominant as the first two challenges are related to the fear of failure of projects (3.4431) and the expectation of losses (3.4132). These challenges can be faced by involving employees in the investment decision-making (Jones, 2005).

Insufficient of the contribution of universities comes third with a mean of 3.3413. This result is consistent with the early result from Gerdes (1971), who criticized in that time the low contribution of employers in national provident fund of six African countries (see also, Dixon, 1993; Estrada, Koutronas \& Park, 2019). The failure to open doors for donations and grants to the EPF ranked fourth with a mean of 3.3234. These two barriers focused mainly on the need of EPF to additional financial support resources.

The unattractive geographic location comes fifth and followed by the inability of bearing risks. Most important, the unavailability of regulations that govern the investment in the EPF comes at the bottom of the list. This result indicates that the employees know that the necessary regulations are available but the problem is centered in using such regulations by the management of EPF in taking rational investment decisions.

Table 7. Barriers of the investments in EPF

\begin{tabular}{lcc}
\hline Item & Mean & Rank \\
\hline E7. The fear from the failure of investment projects & 3.4431 & 1 \\
E8. Expectation of losses & 3.4132 & 2 \\
E10. The contribution of the university to EPF is insufficient & 3.3413 & 3 \\
E11. The failure to open the door for donations and grants to the EPF & 3.3234 & 4 \\
E6. The existence of the EPF in regions that are not attractive to investment & 3.3174 & 5 \\
E5. Inability to bear risks & 3.2994 & 6 \\
E4. The low balances of EPF & 3.2515 & 7 \\
E3. The lack of investment alternatives for the EPF & 3.2395 & 8 \\
E2. The lack of qualified management to direct the investments of EPF & 3.1138 & 9 \\
E9. The contribution of the employees to EPF is insufficient & 3.0659 & 10 \\
E1. The lack of laws and regulations necessary to govern the investment in & 2.9760 & 11 \\
EPF & & 3.2531 \\
\hline Total
\end{tabular}

\section{Future Corrective Actions of EPF}

Finally, the researchers focused on the corrective actions that may be taken by the universities to improve the overall situation of EPFs. In particular, 16 corrective actions were outlined in the questionnaire and the respondents were asked to rank them on a five-point likeret scale ( $1=$ strongly disagree, $5=$ strongly agree). As shown in Table 8 , the total mean value is 3.710 , which indicates a relatively high degree of consensus among the respondents on these actions. In addition, it looks that 
there is a consistency among the respondents as the mean values of all the actions are relatively very close to each other. The results show that respondents are in need for more elastic terms to enable them to withdraw a part of their balances during their work (3.8743). This result is inconsistent with the call from Jones (2005) to put more restrictions on the usage of EPF for the purposes other than the retirement stage. On the other hand, this result supports the result reported in Table 3, where $44.3 \%$ of the respondents wish to withdraw their accumulated balances according to their emergency needs.

The necessity of offering a web page for the EPF on the website of the university ranked second (3.8683). In the same context, the employees ranked the linkage of employee accounts in EPF with their pages on the web sites of universities third. The respondents also interested in benefiting from the other universities experience as it ranked fourth. Respondents also call for enhancing the credit facilities terms. This result is consistent with the findings of Koh, Mitchell and Fong (2010), who stressed the importance of getting professional consultants to effectively enhance the return of Singapore's central provident fund. The respondents interested in enhancing the accounting system used for EPE. In addition, respondents also see that all the employees should participate in EPF. This result is consistent with the findings of Koutronas and Park (2019). Furthermore, respondents invite the management of EPF in Jordanian universities to benefit from the experience of private companies. Moreover, specialized workshops should be held. Most important, respondents see that a specialized management should manage the EPF. In this context, Hassan and Othman (2018) give much emphasis to the presence of such professional management. Respondents are interested in creating additional investment opportunities for the members of EPF. This result is consistent with the call of Koh and Mitchell (2010). The respondents also interested in taking their perceptions in the investment policy (Tuyon \& Ali, 2011).

Table 8. The future corrective actions of EPF

\begin{tabular}{llc}
\hline Item & Mean & Rank \\
\hline F16. Facilitating the terms of getting part of employee's balance in EPF during his work in the & 3.8743 & 1 \\
university & & 2 \\
F7. A comprehensive webpage for EPF should be launched on the university website including & 3.8683 & 2 \\
all the related regulations and instructions & 3.8503 & 3 \\
F8. Linking each employee's account in the EPF with his page on the university's website & 3.8443 & 4 \\
F13. Benefiting from the experiences of other universities (internal and external) in managing & 3.8443 & 4 \\
and investing of EPF & 3.8024 & 6 \\
F9. Terms of credit facilities (loans) of EPF should be facilitated. & 3.7844 & 7 \\
F10. Appropriate and efficient software should be used to manage and account for EPF. & 3.7545 & 8 \\
F4. All the employees of the university should participate in EPF & 3.6946 & 9 \\
F14. benefiting from the experiences of large companies and organizations in managing and & 3.6946 & 9 \\
investing of EPF & 3.6527 & 11 \\
F15. Holding specialized workshops on managing and investing of EPF & 3.5928 & 12 \\
F2. A specialized management should be employed to direct and manage the investments of & 3.5868 & 13 \\
EPF & 3.5868 & 13 \\
F3. Alternative investment opportunities should be created & 3.5269 & 15 \\
F5. Perceptions of members about the EPF potential investment projects should be taken. & 3.4012 & 16 \\
F1. detailed regulations should be developed to direct the investment in EPF & 3.7100 & \\
F11. Experts should be employed to assist in making investment decisions for EPF & \\
F6. An external auditor should be appointed to audit and approve the EPF accounts & \\
F12. Linking EPF with other investment funds in the university &
\end{tabular}


INTERNATIONAL JOURNAL OF ACADEMIC RESEARCH IN ACCOUNTING, FINANCE AND

MANAGEMENT SCIENCES

Vol. 10 , No. 3, 2020, E-ISSN: 2225-8329 @ 2020 HRMARS

\section{Hypotheses Testing}

For the purpose of the first group of hypotheses, it looks from Table 9 that, except for the accounting system, the mean values of the responses on investment current status, accounting system, barriers and future corrective actions are relatively close to each other between the academic and administrative staff and very little variations are found between them. On the other hand, the mean values of accounting system have relatively larger variation. Accordingly, the Independent Sample T-test was performed to test the significance of the differences between means.

Table 9. Descriptive statistics for nature of work (academic and administrative staff)

\begin{tabular}{llcccc}
\hline Factor & Group & $\mathbf{N}$ & Mean & Std. Deviation & Std. Error Mean \\
\hline Current status & Academic & 58 & 2.9207 & 0.90297 & 0.11857 \\
& Administrative & 109 & 2.6954 & 0.95009 & 0.09100 \\
\hline Accounting system & Academic & 58 & 3.2960 & 0.91503 & 0.12015 \\
& Administrative & 109 & 2.8945 & 0.91671 & 0.08781 \\
\hline Barriers & Academic & 58 & 3.2712 & 0.60506 & 0.07945 \\
& Administrative & 109 & 3.2435 & 0.70666 & 0.06769 \\
\hline Corrective actions & Academic & 58 & 3.7586 & 0.74297 & 0.09756 \\
& Administrative & 109 & 3.6841 & 0.86856 & 0.08319 \\
\hline
\end{tabular}

\section{First group: Nature of Work (H1, H2, H3 and H4)}

The first group of hypotheses examines if the presence of nature of work (i.e. academic and administrative) affects the perception of respondents towards the current status of EPF investments, accounting system, barriers of investments in EPF and future corrective actions.

In respect to $H 1$, Table 10 shows that the means difference is not significant $(t=1.484, p=0.140)$. In addition, the lower value of the confidence interval of the difference is negative $(-0.07447)$, while the upper value is positive (0.52503). This means that the confidence interval includes zero (0.000), which means that there is no significant difference. Accordingly, $\mathrm{H} 1$ is rejected. This means that there is no significant difference in the perception of employees towards the current status of EPF investments due to their nature of work (i.e. academic and administrative).

In respect to the perception towards the accounting system, Table 10 shows that the means difference is significant $(t=2.696, p=0.008)$. In addition, the confidence interval has not zero (0.000), which means that there is a difference. Accordingly, $\mathrm{H} 2$ is accepted. This means that there is a significant difference in the perception of employees towards the accounting system used in EPF due to their nature of work. The justification for this result is based on the notion that both academic and administrative staff has different knowledge in the accounting field in general.

In respect to the perception of employees towards the barriers of investment in EPF, the results show that the means difference is not significant $(t=0.252, p=0.801)$. Accordingly, $H 3$ is rejected. This means that there is no significant difference in the perception of employees towards the barriers of investment in EPF due to their nature of work.

Results also show that the means difference is not significant $(t=0.554, p=0.580)$. Accordingly, $\mathrm{H} 4$ is rejected. This means that there is no significant difference in the perception of employees towards the future corrective actions of EPF due to their nature of work. 
INTERNATIONAL JOURNAL OF ACADEMIC RESEARCH IN ACCOUNTING, FINANCE AND MANAGEMENT SCIENCES

Vol. 10 , No. 3, 2020, E-ISSN: 2225-8329 @ 2020 HRMARS

Table 10. Independent Sample T-test results (nature of work)

\begin{tabular}{|c|c|c|c|c|c|c|c|c|c|}
\hline \multirow[t]{2}{*}{$\mathbf{H}$} & & & \multicolumn{2}{|c|}{$\begin{array}{l}\text { Levene's } \\
\text { Test for } \\
\text { Equality of } \\
\text { Variances }\end{array}$} & \multicolumn{3}{|c|}{ t-test for Equality of Means } & \multicolumn{2}{|c|}{$\begin{array}{l}\text { 95\% Confidence } \\
\text { Interval of the } \\
\text { Difference }\end{array}$} \\
\hline & & & $\mathrm{F}$ & Sig. & $\mathrm{t}$ & $\mathrm{df}$ & Sig. & Lower & Upper \\
\hline \multirow[t]{4}{*}{$\mathrm{H} 1$} & Natur & Equal & 1.26 & 0.26 & 1.484 & 165 & 0.14 & - & 0.5250 \\
\hline & $\begin{array}{l}\text { e of } \\
\text { work }\end{array}$ & $\begin{array}{l}\text { variances } \\
\text { assumed }\end{array}$ & 5 & 2 & & & 0 & 0.07447 & 3 \\
\hline & & Equal & & & 1.507 & 121.655 & 0.13 & - & 0.5211 \\
\hline & & $\begin{array}{l}\text { variances not } \\
\text { assumed }\end{array}$ & & & & & 4 & 0.07061 & 6 \\
\hline \multirow[t]{4}{*}{$\mathrm{H} 2$} & Natur & Equal & 0.01 & 0.91 & 2.696 & 165 & 0.00 & 0.10749 & 0.6954 \\
\hline & $\begin{array}{l}\text { e of } \\
\text { work }\end{array}$ & $\begin{array}{l}\text { variances } \\
\text { assumed }\end{array}$ & 1 & 6 & & & 8 & & 7 \\
\hline & & Equal & & & 2.698 & 116.591 & 0.00 & 0.10675 & 0.6962 \\
\hline & & $\begin{array}{l}\text { variances not } \\
\text { assumed }\end{array}$ & & & & & 8 & & 1 \\
\hline \multirow[t]{4}{*}{$\mathrm{H} 3$} & Natur & Equal & 2.26 & 0.134 & 0.252 & 165 & 0.80 & - & 0.2436 \\
\hline & $\begin{array}{l}\text { e of } \\
\text { work }\end{array}$ & $\begin{array}{l}\text { variances } \\
\text { assumed }\end{array}$ & 8 & & & & 1 & 0.18844 & 9 \\
\hline & & Equal & & & 0.265 & 132.837 & 0.79 & - & 0.2340 \\
\hline & & $\begin{array}{l}\text { variances not } \\
\text { assumed }\end{array}$ & & & & & 2 & 0.17882 & 7 \\
\hline \multirow[t]{4}{*}{$\mathrm{H} 4$} & Natur & Equal & 5.76 & 0.01 & 0.554 & 165 & 0.580 & -0.19093 & 0.3400 \\
\hline & $\begin{array}{l}\text { e of } \\
\text { work }\end{array}$ & $\begin{array}{l}\text { variances } \\
\text { assumed }\end{array}$ & 9 & 7 & & & & & 6 \\
\hline & & Equal & & & 0.582 & 132.94 & 0.56 & -0.17904 & .3281 \\
\hline & & $\begin{array}{l}\text { variances not } \\
\text { assumed }\end{array}$ & & & & 1 & 2 & & 6 \\
\hline
\end{tabular}

Second group: Monthly Salary (H5, H6, H7 and H8)

The second group of hypotheses tests if the presence of monthly salary affects the perception of respondents towards the current status of EPF investments, accounting system, barriers of investments in EPF and future corrective actions of EPF. One Way ANOVA test was used to test these hypotheses.

In respect to $\mathrm{H} 5$, Table 11 shows that the means difference is significant $(\mathrm{F}=2.519, \mathrm{P}=0.023)$. This means that $\mathrm{H} 5$ is accepted, which means that there is a significant difference in the perception of respondents towards the current status of EPF investments due to monthly salary.

In respect to the perception of respondents toward the accounting system, results show that the means difference is insignificant $(\mathrm{F}=0.911, \mathrm{P}=0.488)$. This means that $\mathrm{H} 6$ is rejected, which means that there is no significant difference in the perception of respondents towards the accounting system used for EPF due to monthly salary. 
INTERNATIONAL JOURNAL OF ACADEMIC RESEARCH IN ACCOUNTING, FINANCE AND MANAGEMENT SCIENCES

Vol. 10 , No. 3, 2020, E-ISSN: 2225-8329 @ 2020 HRMARS

In respect to the perception of respondents toward the barriers of investment in EPF, results show that the means difference is significant $(\mathrm{F}=3.045, \mathrm{P}=0.008)$. This means that $\mathrm{H} 7$ is accepted, which means that there is a significant difference in the perception of respondents towards the barriers of investment in EPF due to monthly salary.

Table 11 also shows that the means difference is significant $(F=3.944, P=0.001)$. This means that $\mathrm{H} 8$ is accepted, which means that there is a significant difference in the perception of respondents towards the future corrective actions of EPF due to monthly salary.

Table 11. One Way ANOVA results (monthly salary)

\begin{tabular}{lllccccc}
\hline H & Variable & & Sum of & Mean & & Squares \\
& & & df & Square & F & Sig. \\
\hline H5 & Monthly & Between Groups & 12.592 & 6 & 2.099 & 2.519 & 0.023 \\
& salary & Within Groups & 133.292 & 160 & 0.833 & & \\
& & Total & 145.884 & 166 & & & \\
\hline H6 & Monthly & Between Groups & 4.779 & 6 & 0.796 & 0.911 & 0.488 \\
& salary & Within Groups & 139.807 & 160 & 0.874 & & \\
& & Total & 144.585 & 166 & & & \\
\hline H7 & Monthly & Between Groups & 7.668 & 6 & 1.278 & 3.045 & 0.008 \\
& salary & Within Groups & 67.161 & 160 & 0.420 & & \\
& & Total & 74.828 & 166 & & & \\
\hline H8 & Monthly & Between Groups & 14.579 & 6 & 2.430 & 3.944 & 0.001 \\
& salary & Within Groups & 98.571 & 160 & 0.616 & & \\
& & Total & 113.150 & 166 & & & \\
\hline
\end{tabular}

Third group: Tenure of University work (H9, H10, H11 and H12)

The third group of hypotheses examines if the presence of tenure of university work affects the perception of respondents towards the current status of EPF investments, accounting system, barriers of investments in EPF and future corrective actions of EPF. One Way ANOVA test was also used to test these hypotheses.

Table 12 shows that the means difference is insignificant ( $F=2.328, P=0.058)$. This means that $\mathrm{H} 9$ is rejected, which means that there is no significant difference in the perception of respondents towards the current status of EPF investments due to tenure of university work.

In respect to the perception of respondents toward the accounting system, results show that the means difference is insignificant $(F=1.218, P=0.305)$. This means that $\mathrm{H} 10$ is rejected, which means that there is no significant difference in the perception of respondents towards the accounting system used for EPF due to tenure of university work.

Results also show shows that the means difference is significant $(F=2.451, P=0.048)$. This means that $\mathrm{H} 11$ is accepted, which means that there is a significant difference in the perception of respondents towards the barriers of investment in EPF due to tenure of university work.

Finally, results show that the means difference is insignificant $(F=1.029 p=0.394)$. This means that $\mathrm{H} 12$ is rejected, which means that there is no significant difference in the perception of respondents towards the future corrective actions of EPF due to tenure of university work. 
INTERNATIONAL JOURNAL OF ACADEMIC RESEARCH IN ACCOUNTING, FINANCE AND MANAGEMENT SCIENCES

Vol. 10, No. 3, 2020, E-ISSN: 2225-8329 @ 2020 HRMARS

Table 12. One Way ANOVA results (tenure of university work)

\begin{tabular}{|c|c|c|c|c|c|c|c|}
\hline \multirow[t]{2}{*}{$H$} & \multirow[t]{2}{*}{ Variable } & & \multicolumn{2}{|l|}{$\begin{array}{l}\text { Sum of } \\
\text { Square }\end{array}$} & \multicolumn{2}{|l|}{$\begin{array}{l}\text { Mean } \\
\text { Squar }\end{array}$} & \multirow[b]{2}{*}{ Sig. } \\
\hline & & & $s$ & df & e & $\mathbf{F}$ & \\
\hline \multirow{3}{*}{ H9 } & \multirow[t]{3}{*}{$\begin{array}{l}\text { Tenure of } \\
\text { university work }\end{array}$} & $\begin{array}{l}\text { Between } \\
\text { Groups }\end{array}$ & 7.929 & 4 & 1.982 & $\begin{array}{c}2.32 \\
8\end{array}$ & \multirow[t]{3}{*}{0.058} \\
\hline & & $\begin{array}{l}\text { Within } \\
\text { Groups }\end{array}$ & 137.955 & 162 & \multirow[t]{2}{*}{0.852} & & \\
\hline & & Total & 145.884 & 166 & & & \\
\hline \multirow{3}{*}{$\mathrm{H} 10$} & \multirow[t]{3}{*}{$\begin{array}{l}\text { Tenure of } \\
\text { university work }\end{array}$} & $\begin{array}{l}\text { Between } \\
\text { Groups }\end{array}$ & 4.220 & 4 & $\begin{array}{c}1.05 \\
5\end{array}$ & \multirow[t]{3}{*}{1.218} & \multirow[t]{3}{*}{0.305} \\
\hline & & $\begin{array}{l}\text { Within } \\
\text { Groups }\end{array}$ & 140.365 & 162 & \multirow[t]{2}{*}{0.866} & & \\
\hline & & Total & 144.585 & 166 & & & \\
\hline \multirow{3}{*}{$\mathrm{H} 11$} & \multirow[t]{3}{*}{$\begin{array}{l}\text { Tenure of } \\
\text { university work }\end{array}$} & $\begin{array}{l}\text { Between } \\
\text { Groups }\end{array}$ & 4.269 & 4 & $\begin{array}{l}1.06 \\
7\end{array}$ & \multirow[t]{3}{*}{2.451} & \multirow[t]{3}{*}{0.048} \\
\hline & & $\begin{array}{l}\text { Within } \\
\text { Groups }\end{array}$ & 70.559 & 162 & \multirow[t]{2}{*}{0.436} & & \\
\hline & & Total & 74.828 & 166 & & & \\
\hline \multirow{3}{*}{$\mathrm{H} 12$} & \multirow[t]{3}{*}{$\begin{array}{l}\text { Tenure of } \\
\text { university work }\end{array}$} & $\begin{array}{l}\text { Between } \\
\text { Groups }\end{array}$ & 2.804 & 4 & 0.701 & \multirow[t]{3}{*}{$\begin{array}{c}1.02 \\
9\end{array}$} & \multirow[t]{3}{*}{0.394} \\
\hline & & $\begin{array}{l}\text { Within } \\
\text { Groups }\end{array}$ & 110.346 & 162 & 0.681 & & \\
\hline & & Total & 113.150 & 166 & & & \\
\hline
\end{tabular}

To sum up, it has found that there is a significant difference in the perception of employees towards the accounting systems used to account for EPF due to their nature of work. Results also revealed that there is a significant difference in the perception of respondents towards the current status of provident investment due to monthly salary. In addition, there is a significant difference in the perception of respondents towards the barriers due to monthly salary. Furthermore, there is a significant difference in the perception of respondents towards the future correction actions due to monthly salary. Finally, result indicated that there is a significant difference in the perception of respondents towards barriers of investment in EPF due to university work tenure. Accordingly, the results show that the monthly salary is the dominant as it affects in the perception of respondents toward three issues of four.

\section{Conclusion}

The current study comes to fill a big gab in the current literature through online survey of 167 employees in two Jordanian public universities lay at south Jordan to investigate their perceptions toward several issues in respect to EPF. The results show the following:

1. Most of the respondents wish to withdraw their accumulated balances according to their emergency needs. 
2. The current investment perspectives of EPF are very few with very low return.

3. The respondents are dissatisfied with the ways the universities follow in investing the accumulated balances of EPF.

4. The respondents are not familiar with the accounting system that used to account for EPF.

5. The uncertainty in the expected results of the potential investments and the inefficiency of management in employing the accumulated balances of EPF are the main barriers of EPF investments.

6. Several future corrective actions are approved by the respondents to effectively direct the EPF to sound investment directions.

7. The monthly salary of the respondents is found to be the main factor that influences the perception of respondents towards the different issues of the current study. In particular, it is found that the monthly salary is affected the perception of respondents towards the current status of EPF investments, the barriers of investment in EPF, and the future corrective actions of EPF.

The EPF is one of the financial schemes that employees in Jordan interest in. Therefore, policy makers in Jordanian universities have the responsibility to direct their efforts to effectively exploit all the available opportunities to develop the EPF. Examples include, first, the instructions of EPF are in need for amendments to meet the desires of all employees. Second, employees must be involved in the various investment polices of EPF. Third, a comprehensive detailed study should be conducted to select the effective and feasible investments for EPF. Fourth, the finance sources of EPF should be diversified to include donations and any other possible resources. Fifth, the membership base should be expanded to include all the university employees according to specific rules. Sixth, technology should be employed in all the aspects of EPF. These include, for example, establishing high quality electronic pages for the EPF and using high-quality accounting system software. Seventh, the current corporate governance practices should be employed in the different aspects of EPF (Lindeman, 2002; Alam, 2010). Finally, the experiences should be exchanged with other universities and private companies to develop EPF.

The current study is considered one the first studies that interested in EPF in universities. Therefore, it contributes effectively in the knowledge in this field and gives the policy-makers fruitful ideas about the necessary actions to develop the different perspectives of EPF in universities and other organizations in developing countries which suffer a severe scarcity in such studies.

Despite that the current study is an initial in this topic; it opens the avenue for several future research opportunities. First, the future studies may use the current study instrument to investigate the status of EPF in different organizations and countries. Second, future studies may depend on the current study to perform a qualitative study to deeply identify the status of EPF in universities. Finally, the reliability test for the main factor that used in this study was performed. These factors may be further validated in future studies by conducting abroad set of empirical studies in this topic. For example, future studies may examine the effect of the investment policy of EPF and corrective actions on the welfare of employees.

The current study is considered a pioneer in this field as it offers a unique reference to the knowledge in provident fund topic in general and in EPF in universities in particular. In addition, the study discusses important issues in the topic and presents a broad set of potential corrective actions that can policy-makers employ in different aspects of EPF. Furthermore, the study provides an initial reference for the future studies in this topic. 
INTERNATIONAL JOURNAL OF ACADEMIC RESEARCH IN ACCOUNTING, FINANCE AND

MANAGEMENT SCIENCES

Vol. 10 , No. 3, 2020, E-ISSN: $2225-8329$ @ 2020 HRMARS

\section{References}

Alam, M. S. (2010). EPFs in Bangladesh: A legal framework for developing countries. Australian Journal of Asian Law, 12(2), 214-247.

Asher, M. G., \& Bali, A. S. (2013). Fairness and Sustainability of Pension Arrangements in Singapore: An Assessment. Malaysian Journal of Economic Studies, 50(2), 175-191.

Bepristis, M., \& Yin, X. (2006). Defined Benefit Pension Fund Accounting: Relevancy, Clarity, and Consistency. Journal of American Academy of Business, Cambridge, 9(2), 294-299

Budsaratragoon, P., Lhaopadchan, S., Clacher, I., Hillier, D., \& Hodgson, A. (2012). Allowing flexible personal savings and investment choices in public sector pension plans-implications from an emerging economy. Accounting, Accountability \& Performance, 17(1-2), 1-21.

Burell, M. (2006). China's Housing Provident Fund: Its Success and Limitations. Housing Finance International, 20(3), 38-49.

Chalamwong, Y., \& Meepien, J. (2012). Poverty and Just Social Protection in Thailand. ASEAN Economic Bulletin, 29(3), 230-244. doi:10.1355/ae29-3e

Chan, C. (2003). Protecting the ageing poor or strengthening the market economy: the case of the Hong Kong Mandatory Provident Fund. International Journal of Social Welfare, 12(2), 123131.

Chen, J., \& Deng, L. (2014). Financing Affordable Housing Through Compulsory Saving: The TwoDecade Experience of Housing Provident Fund in China. Housing Studies, 29(7), 937-958.

Chu, P. K., \& McKenzie, M. (2008). A Study on Stock-Selection and Market-Timing Performance: Evidence from Hong Kong Mandatory Provident Funds (MPF). Review of Pacific Basin Financial Markets \& Policies, 11(4), 617-649.

Cook, S., \& Pincus, J. (2014). Poverty, inequality and social protection in Southeast Asia: an introduction. Journal of Southeast Asian Economies, 31(1), 1-17.

Damle, D. G. (2016). Provident Funds for Workers. The Indian Journal of Social Work, 12(2), 164-170.

Davis, E. P. (2005). Pension fund management and international investment- A global perspective. Pensions: An International Journal, 10(3), 236-261.

Devereux, S. (2013). Trajectories of social protection in Africa. Development Southern Africa, 30(1), 13-23. doi:10.1080/0376835X.2013.755871

Dixon, J. (1982). Provident funds in the third world: A cross-national review. Public Administration and Development, 2(4), 325-344.

Dixon, J. (1993). National provident funds: The challenge of harmonizing their social security, social and economic objectives. Review of Policy Research, 12(1-2), 197-213.

Estrada, M. A. R., Koutronas, E., \& Park, D. (2019). National Social Protection Fund: The Multi-Pillar Employees' Provident Fund. PLATFORM- A Journal of Management \& Humanities, 2(1), 1-12.

Gerdes, V. (1971). African provident funds. Industrial and Labor Relations Review, 24(4), 572-587.

Godfrey, V. N. (1974). A broader role for national provident funds: the Zambian experience. International Labour Review, 109(2), 137-152.

Hamid, T., \& Tyng, C. (2013). Meeting the Needs of Older Malaysians: Expansion, Diversification and Multi-sector Collaboration. Malaysian Journal of Economic Studies, 50(2), 157-174.

Hassan, S., \& Othman, Z. (2018). Forecasting on the long term sustainability of the employees provident fund in Malaysia via the Box-Jenkins' ARIMA model. Business and Economic Horizons (BEH), 14,43-53. 
INTERNATIONAL JOURNAL OF ACADEMIC RESEARCH IN ACCOUNTING, FINANCE AND

MANAGEMENT SCIENCES

Vol. 10 , No. 3, 2020, E-ISSN: $2225-8329$ (c) 2020 HRMARS

Hassan, S., Othman, Z., \& Din, W. Z. W. (2018). Does the Employees Provident Fund Provide Adequate Retirement Incomes to Employees?. Asian Journal of Economics, Business and Accounting,7(1), 1-11.

Holzmann, R. (2013). Global pension systems and their reform: Worldwide drivers, trends and challenges. International Social Security Review, 66(2), 1-29

Jidwin, A., Tuyon, J., \& Ali, R. (2011). The Malaysian Employees Provident Fund's Members' Investment Scheme: Survey of Fund Selection, Performance and Perceptions. Asia-Pacific Management Accounting Journal, 6(1), 47-79.

Jones, D. S. (2005). The central provident fund scheme in Singapore: Challenges and reform. Asian Journal of Political Science, 13(2), 75-102.

Kathuria, L. M., \& Singhania, K. (2012). Investment Decision Making: A Gender-Based Study of Private Sector Bank Employees. IUP Journal of Behavioral Finance, 9(1), 45-56.

Klumpes, P. M. (2011). The changing political economy of pension fund accounting regulation: A comparative study of four Anglo-American countries. Pensions: An International Journal, 16(3), 140-150. doi:10.1057/pm.2011.11

Koh, B. K., \& Mitchell, O. S. (2010). What's on the menu? Included versus excluded investment funds for Singapore's Central Provident Fund investors. Pensions: An International Journal, 15(4), 276-286.

Koh, B. K., Mitchell, O. S., \& Fong, J. Y. (2008). Cost structures in defined contribution systems: The case of Singapore's central provident fund. Pensions: An International Journal, 13(1-2), 7-14. doi:10.1057/pm.2008.3

Koh, B. K., Mitchell, O. S., \& Fong, J. H. (2010). Collective investments for pension savings: Lessons from Singapore's Central Provident Fund scheme. Pensions: An International Journal, 15(2), 100-110. doi:10.1057/pm.2009.33

Kumara, A. S., \& Pfau, W. (2012). Reforming Pension funds in Sri Lanka: International Diversification and the Employees' Provident Fund. Australian Economic Papers, 51(1), 23-37.

Lindeman, D. C. (2002). Provident funds in Asia: Some lessons for pension reformers. International Social Security Review, 55(4), 55-70.

Nazir, N., Hamidullah \& Hussain, A. (2010). A Thorn by the Name of Rose: General Provident Fund, Interest Bearing Activity or Tohfa-e-Sultani. Journal of Managerial Sciences, 4(2), 178-188.

Nunnally, J. C. (1978). Psychometric theory (2nd ed.). New York: McGraw-Hill.

Ramesh, M. (2014). Social protection in Indonesia and the Philippines: work in progress. Journal of Southeast Asian Economies, 31 (1), 40-56.

Saha, S., \& Dey, M. (2011). Analysis of Factors Affecting Investors' Perception of Mutual Fund Investment. The IUP Journal of Management Research, 10(2), 23-44.

Shanmugasundaram, B. (2008). A Critical Appraisal of the Law on Employee Provident Fund Scheme in India and Perspectives of EPF in Malaysia and Sri Lanka. The Icfai University Journal of Employment Law, 6(3), 68-89.

$\mathrm{Siu}, \mathrm{A}$. (2002). Hong Kong's mandatory provident fund. Cato Journal, 22(2), 317-332.

Thillainathan, R. (2000). The Employees Provident Fund of Malaysia: Asset allocation, Investment Strategy and Governance Issues Revisited. Paper presented at the Pension Fund Management, August 14-15, Kuala Lumpur, Malaysia. 
Unachukwu, J. C., A Oladeji, A., \& O Egunjobi, G. (2020). Public Workers' Perception towards Contributory Pension Scheme: Evidence from Lagos State, Nigeria. Asian Journal of Education and Social Studies, 8(4), 8-15.

Vasoo, S. S., \& Lee, J. (2001). Singapore: social development, housing and the Central Provident Fund. International Journal of Social Welfare, 10(4), 276-283

White, M. (2005). Returns from Fiji National Provident Fund: Accounting Myth vs Economic Reality. Fijian Studies: A Journal of Contemporary Fiji, 3(1), 1-19.

Wu, Y., \& Wang, R. (2003). Monetary Sterilization of Capital Inflows through the Central-ProvidentFund Savings in Singapore. Review of Pacific Basin Financial Markets \& Policies, 6(1), 65.

Zhu, H. J. (2019). The Impact of Home Equity and Housing Provident Fund on the Household's Stock Investment. Open Journal of Social Sciences, 7(8), 222-240. doi: 10.4236/jss.2019.78016.

Zin, R. M. (2012). Malaysia: towards a social protection system in an advanced equitable society. ASEAN Economic Bulletin, 29(3), 197-217. 